
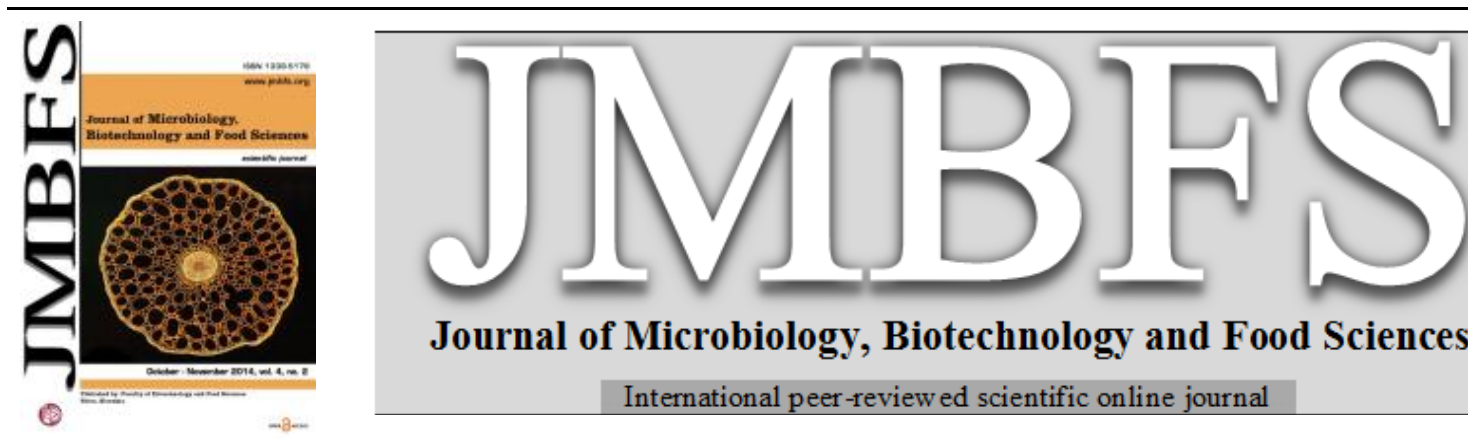

Journal of Microbiology, Biotechnology and Food Sciences

International peer-review ed scientific online journal

\title{
NUTRITIONAL STRESS IN WESTERN HOOLOCK GIBBON DUE TO ADVERSE CHANGES IN DIET PATTERN
}

\author{
Mitrajit Deb $^{1}$, Sudip Choudhury ${ }^{2}$, Indu Sharma ${ }^{3}$, Parimal C. Bhattacharjee ${ }^{4}$, Grzesiek Formicki ${ }^{5}$, Jozef Bulla ${ }^{6}$ and Shubhadeep \\ Roychoudhury ${ }^{1 *}$
}

\author{
$\operatorname{Address}(e s):$ \\ ${ }^{1}$ Department of Life Science and Bioinformatics, Assam University, Silchar 788 011, India. \\ ${ }^{2}$ Department of Chemistry, Assam University, Silchar 788 011, India. \\ ${ }^{3}$ Department of Microbiology, Assam University, Silchar 788 011, India. \\ ${ }^{4}$ Wildlife Trust of India, Guwahati 781012, India. \\ ${ }^{5}$ Department of Vertebrate Zoology \& Human Biology, Institute of Biology, Pedagogical University of Cracow, 31054 Cracow, Poland. \\ ${ }^{6}$ Department of Animal Physiology, Slovak University of Agriculture, 31054 Nitra, Slovak Republic.
}

*Corresponding author: shubhadeep1@gmail.com

doi: 10.15414/jmbfs.2014.4.2.152-156

\section{ARTICLE INFO}

Received 9. 7. 2014

Revised 22. 8. 2014

Accepted 2. 9. 2014

Published 1. 10. 2014

\section{Review}

open 2 access

\begin{abstract}
Habitat destruction and hunting are one of the major threats to endangered western hoolock gibbon (Hoolock hoolock) in India. Due to large scale deforestation, important feeding and roosting tress are destroyed thereby creating shortage of food all-round the year. In nonavailability of preferred food, these gibbons are bound to switch their diet and eat a diet of less nutritive value. This unwanted dietswitch may lead to severe nutritional stress leading to low population densities, reduced litter and a breach in their nutritional threshold may also cause sudden die-off. Acute food supply may cause deficiency of total energy and protein supply in primates which may ultimately lead to a variety of severe immune dysfunctions and an impaired resilience. It is being well known that degraded habitat leads to increase of parasite among primates, which leads to the decimation of the weak and the vulnerable. Weak immune system due to improper diet and nutrition may lead to parasite colonization, growth and fecundity.
\end{abstract}

Keywords: Western hoolock gibbon, endangered, nutritional stress, low population density, immune dysfunction, parasite

\section{INTRODUCTION}

Northeast India sustains quite an overwhelming number of primates, due to the recent revisions in primate taxonomy. Earlier the genus Bunopithecus comprised two subspecies western and eastern hoolock gibbon. But, thorough taxonomical revisions by Mootnick and Groves (2005) placed them in a new genus, Hoolock, as two distinct species, the western hoolock gibbon being Hoolock hoolock and the eastern hoolock gibbon, Hoolock leuconedys.

The western hoolock gibbon (Hoolock hoolock) occurs in the western-most extreme of the distribution of the 16 gibbon species currently recognized (Geissmann, 2007). Its range between the Brahmaputra and Chindwin rivers takes in three countries: Bangladesh, India and Myanmar. Preliminary surveys in Myanmar indicated that it occurs at least as far south as Rakhine Yoma in southwest Myanmar (Geissmann et al., 2008). It has been on the list of the World's 25 Most Endangered Primates since 2006 (Walker et al., 2007), with the global population estimated to be about 5,000 animals: 2600 to 4450 in India (Molur $\boldsymbol{e t}$ al., 2005; Choudhury, 2006), and about 200 in Bangladesh (Molur et al., 2005). Most populations of the western hoolock gibbon are isolated and small, with $80 \%$ of those assessed in India and Bangladesh harbouring fewer than 20 individuals, and over half having fewer than 10 (Walker et al., 2007). Despite the wide area in which the animal occurs, it has become a rare animal, all over its range. Molur et al. (2003) pointed out that gibbons are losing 3-4\% of their habitat every year and their population is declining by $1-2 \%$ in a year in their distributional range. The rapid destruction and alteration of habitat (by plantation of exotic monoculture species) that continues in an unplanned manner will undoubtedly result in the extinction of the species (Muzaffar et al., 2006). Molur et al. (2005) also stated that the isolated forest fragments holding the families of about 2-4 individuals are insufficient for long-term survival of the western hoolock gibbon. Tropical rain-forest is the most threatened primate habitat, because of its economic importance and because its inhabitants are more specialized in their arboreal adaptations than those primates exploiting more terrestrial niches. Since such primates are wholly or mostly arboreal, and because they are among the largest of forest animals, they are excellent indicators of the health of the forests concerned, and, because of their close relationship to humans, ideal focal or flagship species for publicising the threats to their ecosystem which one is seeking to conserve for humans as well as primates, and all the other animals and plants on which they depend (Chivers, 1984).

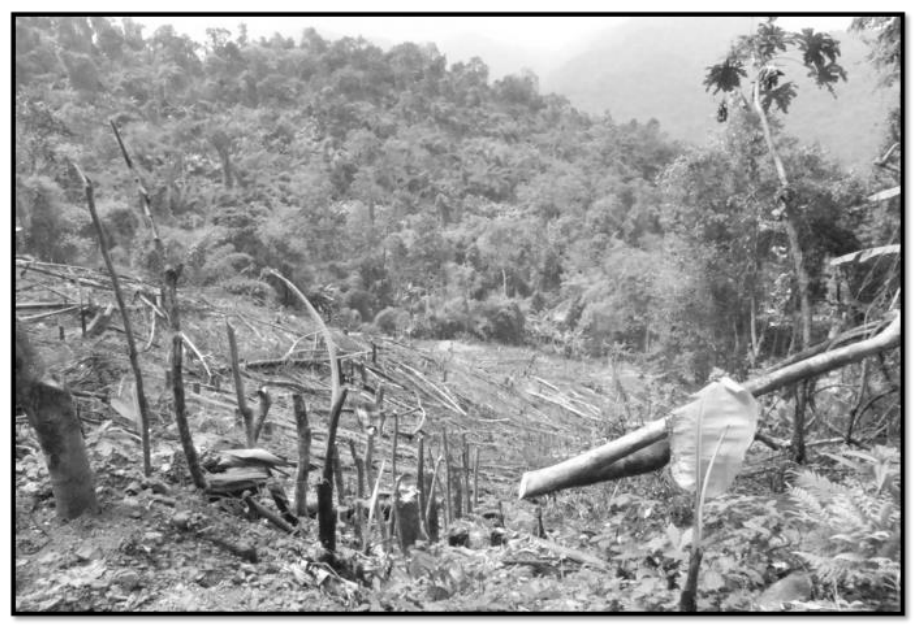

Figure 1 Large scale deforestation causing destruction of western hoolock gibbon habitats

Due to large scale habitat destruction, the food sources of these primates have drastically reduced and the western hoolock gibbons are bound to eat a diet with less nutritive value which has acutely impacted the population of these endangered primates. Thus, poor nutrition is also posing as a threat for the survival of western hoolock gibbons (Gupta, 2005).

There are three broad categories of major threats to primate populations in the wild: habitat destruction, hunting for food and other purposes; and live capture for export and local trade (Mittermeier, 1984). According to Wolfheim (1983), primates are vulnerable to disturbance due to various reasons such as requirement 
of more food and space, they usually occur at low densities, breed more slowly, are more vulnerable to hunters and tend to be more recently derived and specialized.

As in case of western hoolock gibbons, the various adaptations such as strict canopy dwelling, fruit-pulp specializing diet and brachiating makes them highly vulnerable in tropical ecosystems. Moreover, monogamous nature, small group size, slow growth rate, long inter-birth interval have multiplied the effect (Das $\boldsymbol{e}$ al., 2003). Most of the tropical forests that harbour this species are subjected to slash and burn or shifting cultivation and therefore, the species habitat is highly degraded and fragmented. It is hunted for the pot and the belief that its flesh and blood have medicinal properties has made it a highly prized commodity. It is also highly prized in the pet trade. All these are detrimental to the survival of the species (Srivastava, 2006).

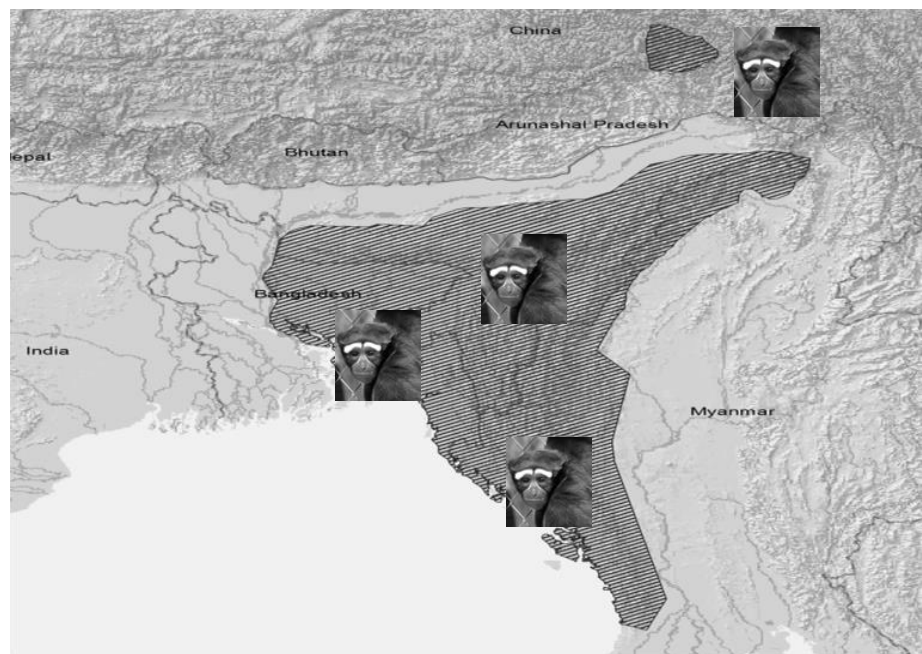

Figure 2 The global distribution of western hoolock gibbon (Adapted from Brockelman et al., 2008)

\section{MATERIAL AND METHODS}

In the present study literature had been reviewed on nutritional and dietary aspects of gibbons in general. The literature reports were collected concerning the common diets and nutritional sources of western hoolock gibbons in particular. The methodology followed for the preparation of this research paper is as follows:

1. The published reports on dietary sources and nutritional aspects of western hoolock gibbons were recorded by literature survey such as research journals both online and print, books, monographs, etc.

2. All major databases such as PubMed, NCBI and other repositories were thoroughly searched and suitable research papers were downloaded.

3. The Indian Wildlife (Protection) Act in 1972 was studied for procuring the exact status of western hoolock gibbon.

4. The IUCN Red List data file available online was downloaded and analysed for most accurate and authentic information.

5. Apart from the above, reports and communication by major societies such as International Primatological Society, ICZN, etc. were thoroughly studied and analysed.

\section{RESULTS AND DISCUSSION}

After extensive literature survey some common sources of nutrition and dietary pattern of western hoolock gibbons are noted. The changes over the years which have caused a marked shift in the dietary pattern of western hoolock gibbon has also been analyzed and studied. The various aspects of nutrition has been dealt with and discussed below. The two main aspects such as "nutritional stress" and "diseases caused due to poor nutrition or malnutrition" has been discussed at length and given proper attention throughout the paper.

\section{Nutritional stress in western hoolock gibbons:}

All gibbons are fruit-pulp specialists (Chivers, 1984) with simple stomachs and a very limited ability to digest leaf material. Unlike monkeys, they cannot cope with secondary compounds and toxins in leaves, and they prefer animal to plan protein in times of fruit-shortage (Vellayan, 1981). Prolonged dependence on leaves can thus cause severe nutritional stress, especially in the juveniles. Although adults might persist and breed for a time in sub-optimal habitats, a sudden die-off may occur when eventually their nutritional tolerance threshold is breached (Kakati et al., 2009).

Reductions in fruit supply and species richness of fruit trees due to disturbance and fragmentation have been documented in forest habitats (Johns, 1986;
Tabarelli et al., 1999). Reduced fruit supply in turn has been linked to low population densities and declines of primate frugivores in fragments in Mexico, the Atlantic forest of Brazil, and the Central Amazon (Estrada and Coates-Estrada, 1996; Chiarello and Melo, 2000; Gilbert and Setz, 2001). The survival ability of several other rain-forest primates, including gibbons, has been negatively correlated to its degree of frugivory (Johns and Skorupa, 1987). In undisturbed areas, the natural seasonal cycles of fruit shortage in tropical habitats may be offset by the presence of keystone species. For example, one study conducted in Peru revealed that $<1 \%$ of the tree species sustained the entire frugivore community through a period of three months of low fruit availability in Cocha Cashu (Terborgh, 1983).

Recent evidence from Kibale indicates that reduced food availability has resulted in dietary stress in redtail guenons in logged forests (Chapman et al., 2005) These guenons have a lower intake of crude protein and key minerals compared with guenons in undisturbed forests. Such protein and mineral deficiencies have been linked to depressed immune function (Chandra, 1983; Bundy and Golden, 1987; Koski and Scott, 2001). In addition, nutrient content varies more among food items for guenons compared with colobines at Kibale (Chapman et al. 2005). Thus, variation in nutritional condition is likely to be more sensitive to changes in habitat for guenons than for colobines. Hence, dietary stress may increase susceptibility of redtail guenons in logged forest to infection, contributing to the altered pattern of parasitism observed (Gillespie et al., 2005).

In a fragment forest, however, this vital availability might be easily disrupted Across five intensive study sites in Assam, Kakati (2006) found that during the dry, winter season gibbon groups in all the forests shifted from a predominantly fruit diet to eating leaves. Even then, the gibbon groups in the medium-sized and large forests continued to eat at least $14-28 \%$ fruit (as percent time spent feeding), whereas the small fragment groups had practically no fruit at all for two months (January-February). Such extreme shortage of high-energy fruit could be the critical point on which hinges the survival of gibbons in small fragments. An ideal western hoolock gibbon diet includes $65 \%$ fruits, $13 \%$ leaves, $12 \%$ petioles and flower buds, $5 \%$ flowers and $5 \%$ animal protein. They acquire these items from a number of food plants (trees, climbers, stranglers, lianas, etc) from their habitats. Ficus forms the single largest genus and can be regarded as the primary food source of western hoolock gibbon. They acquire 35-60\% food from Ficus especially during dry spell (Chetry et al., 2007). Thus, the loss of Ficus trees from the habitats of western hoolock gibbons may be extremely detrimenta as it may cause acute shortage of food in dry spells. This will inevitably cause nutritional stress among the individuals of the troop.

Although figs are reported to be poor in nutritional quality, they play an important role in sustaining frugivores in lean seasons when alternative food resources are scarce. Fig's aseasonal fruiting, large crop sizes, intra-crown synchrony of fruit ripening and the relatively short intervals between fruiting in individual trees (Lambert, 1989) are traits that enable them to fulfil the role of lean season resource. Self standing fig trees in disturbed habitats are known to produce superabundant fruit crops (Peres, 1994). Habitat quality influences the feeding behaviour of western hoolock gibbons in degraded habitats (Chetry et al., 2004).

Western hoolock gibbon females in fragments probably suffer very high lactation costs because of inadequate diets in terms of both quality and quantity. Many mammals under conditions of seasonal food shortages are known to rear a reduced litter or females may not survive to breed again (Moir, 1994). Weaning is thought to be the critical time that foods of particularly high nutrient density are required (Oftedal, 1991), and western hoolock gibbon infants might be surviving the entire two-year period of dependency on the mother at this high cost to her, only to die when they stop suckling.

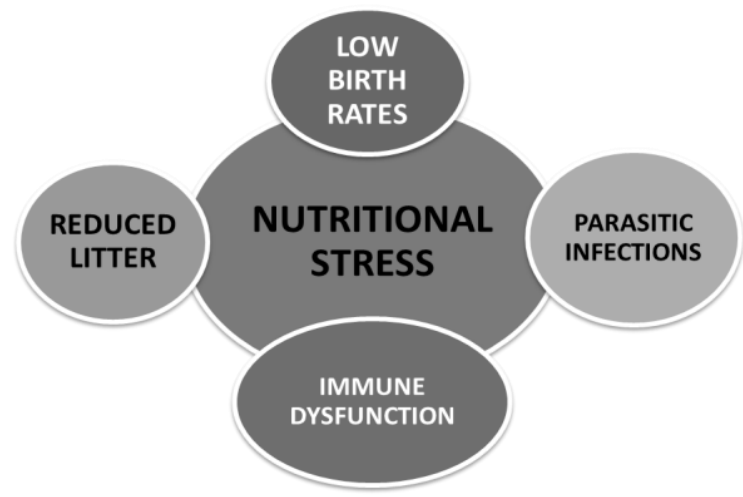

Figure 3 A diagram showing consequences of nutritional stress in western hoolock gibbons 


\section{Nutritional status and diseases:}

Not only quality but also the quantity of the host's diet has a major effect on parasite infection. The importance of the host's nutritional status for the function of the immune system is generally accepted (Bundy and Golden, 1987; Coop and Holmes, 1996; Coop and Kyriazakis, 2001; Koski and Scott, 2001; Nelson and Demas, 2004). The nutritional status can influence parasitism mainly in two aspects: firstly, it influences host defences which regulate parasite colonization, growth and fecundity (resistance). Secondly, it can affect the capability to cope with the pathophysiological consequences of parasite infection (resilience) (Gibson, 1963; Holmes, 1993; Beisel, 1996; Coop and Holmes, 1996; Coop and Kyriazakis, 2001)

Malnutrition, which is characterized by a deficiency of total energy and protein supply leads to a variety of severe immune dysfunctions and an impaired resilience (Gibson, 1963; Bundy and Golden, 1987; Beisel, 1996; Coop and Kyriazakis, 2001). In seasons with low food availability and/or quality or in situations of higher energy demands (growth, late pregnancy and lactation), malnutrition can impair the immune system even more pronouncedly (Coop and Kyriazakis, 2001).

Animals suffering malnourishment combined with parasite infection enter a vicious circle: malnutrition enhances parasite infection and intestinal parasites in turn reduce food uptake and resource utilization and increase protein loss into the intestinal lumen (Gibson, 1963; Koski and Scott, 2001). The parasite diversity and prevalence is expected to be higher in hosts of a poor nutritional status or in period of food scarcity. Parasites can exert an important impact on hos population regulation in terms of reducing fecundity and/or survival of the hos individuals (Scott and Dobson, 1989; Hudson et al., 2002). They can even lead to rapid declines of host populations or host species extinctions (Daszak, 2000; Harvell et al., 2002).

The free ranging wild animals often encounter "Emerging Infectious Diseases (EIDs)". The major sources for EIDs are "spill-over" from domestic animals to wildlife populations living in close vicinity and most alarming cause is the human intermediation via host or parasite translocations. This causes serious biologica implications where many wild animal species act as 'disease pools of pathogens' threatening domestic animal and human health; and wildlife EIDs pose a substantial threat to the conservation of global biodiversity (Daszak et al, 2000). Often in zoos the wild animals are under stress conditions and are exposed to parasitic infection. Various zoo reports show parasite infestation such as in Dhaka zoo, Balantidium coli and Trichuris sp. were reported from captive western hoolock gibbons (Raja, 2012). Another study in Assam Zoo recorded ova of Trichuris sp. in western hoolock gibbon (Nath et al., 2012). Muangkram et al. (2006) also found gibbons infected with hookworm eggs, whipworm eggs, large roundworm eggs, coccidian oocysts, Giardia and Trichomonad. These findings demonstrate the prevalence of parasites in gibbons which may exacerbate due to acute stress conditions. Thus nutritional stress in wild western hoolock gibbons may cause vulnerability as with increased human-animal contact in this century. The encroaching humans with their domesticated animals may act as a pathogen reservoir. The western hoolock gibbon immunity may not evolve for these new pathogens and much population may perish if they are not checked in proper time.

\section{CONCLUSION}

Western hoolock gibbons with their acute adaptations are highly adapted for tropical forests which are rich in variety of food all-round the year. Even in fallback time of the year, the forest has few food trees which provide optimum nutrition for the survival of the endangered western hoolock gibbon. The recent surveys in various habitats of India and other countries have shown an unprecedented decline in gibbon population all around the world. Western hoolock gibbon, the unique ape of India also faces innumerable threats which have endangered its existence. Tilson (1979) estimated 24,500 individuals of western hoolock gibbons in 7,650 groups in $3,480 \mathrm{~km}^{2}$ of available tropical evergreen forest habitat in Meghalaya. Since then, the total population of western hoolock gibbon in South Asia has drastically dwindled to a meager 3,000 estimated individuals (Walker and Molur, 2007).

The presence and abundance of several primate species are strongly associated with the presence of their most important food resources (Arroyo-Rodriguez et al., 2007; Balcomb et al., 2000; Cristobal-Azkarate et al., 2005; Estrada and Coates-Estrada, 1996; Rovero and Struhsaker, 2007; Stevenson, 2001), hence it is crucial to consider these top food species as a priority for conservation to develop effective management and restoration plans (Gonzalez-Zamora $\boldsymbol{e t}$ al., 2008).

The seasonality in the fruit production further leads to the paucity of food resources in these already fragmented habitats. This scarcity in food resources may lead to the severe nutritional stress. The fragmentation also causes unavailability of food resources in required quantity and density leading to the nutritional gaps, especially for the lactating and breeding females, which may sometimes prove fatal. Selective removal of fruit trees and especially the citrus fruit trees has led to the decimation of the gibbon population across its habitat (Gupta and Sharma, 2005).

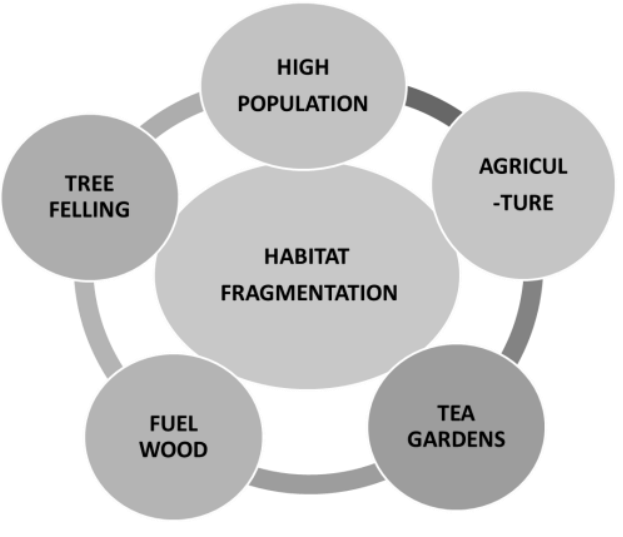

Figure 4 Important causes of habitat fragmentation

Muzaffar et al. (2006) demonstrated that a key habitat feature associated with the survival of western hoolock gibbons is edible plant species richness. The proper amount of nutrition is required by all organisms for growth and overall development. At most times, these degraded habitats fall far short in meeting even the optimum requirements of food, cover and water for western hoolock gibbons. This renders western hoolock gibbons weak and vulnerable to diseases, infections, and other destructive forces. Together with these threats, the inbred populations run the risk of getting totally wiped out in near future (Gupta and Sharma, 2005)

Thus, it can be concluded that in spite of the most preferred food plants being available in habitats of western hoolock gibbons, the accessibility of gibbons to these food plants have decreased due to canopy gaps and other kinds of biotic disturbances. This poor accessibility has forced the gibbons to take to folivory. The present study recommends the government agencies to take immediate measures to save this ape from extinction. The western hoolock gibbons of poor habitats which are insufficient to provide necessary nutrition should be translocated to viable habitats as soon as possible.

To save this species in nature, their habitat must be protected from further degradation and loss. For reviving their population and establishment of new groups in particular, the corridors between the existing forest patches should be developed by planting tropical semi-deciduous and tropical deciduous tree species such as Grewia disperma, Dalbergia pinnata, Dalbergia assamica, Bauhinia purpurea, Vitex glabata, Artocarpus lakoocha, Ficus benjamina, F bengalensis, $F$. concinna, $F$. pomifera, $F$. nervosa $F$. globella, F. geniculata, Dendrobium bicaneratum, Cephalostachyum latifolium, Dendrocalamus hookerii, etc. (Sati, 2011). Improvement of habitat should involve carefully planned plantations of mixed native species providing food and habitat for western hoolock gibbons (Muzaffar et al., 2006).

Acknowledgements: We wish to thank our companions, helpers and guides. We would like to thank the anonymous reviewers who gave valuable inputs into the review and their constructive comments.

\section{REFERENCES}

ARROYO-RODRI'GUEZ V, MANDUJANO S, BENI'TEZ-MALVIDO J, CUENDE-FANTO'N.C. 2007. The influence of large tree density on howler monkey (Alouatta palliate mexicana) presence in very small rainforest fragments. Biotropica, 39, 760-766. http://dx.doi.org/10.1111/j.1744-7429.2007.00330.x BALCOMB S.R., CHAPMAN C.A., WRANGHAM R.W. 2000. Relationship between chimpanzee (Pan troglodytes) density and large, fleshy fruit tree density: conservation implications. American Journal of Primatology, 51, 197 203. http://dx.doi.org/10.1002/1098-2345 (200007) 51:3<197::aid-ajp4>3.0.co;2-

BEISEL, W.R. 1996. Nutrition in pediatric HIV infection: setting the research agenda. Nutrition and immune function: overview. Journal of Nutrition, 126 2611S-2615S

BROCKELMAN, W., MOLUR, S., GEISSMANN, T. 2008. Hoolock hoolock The IUCN Red List of Threatened Species. Version 2014.1. <www.iucnredlist.org>

BUNDY, D.A., GOLDEN, M.H.N. 1987. The impact of host nutrition on gastrointestinal helminth populations. Parasitology. 95, 623-635. http://dx.doi.org/10.1017/s0031182000058042

CHAPMAN, C.A., WASSERMAN, M.D., GILLESPIE, T.R. 2006. Behavioural patterns of colobus in logged and unlogged forests. In Developments in Primatology: Progress and Prospects. Springer Science + Business Media. ISSN: 10.1007/978-0-387-33505-6_21 
CHETRY, D., BHATTACHARJEE, P.C., MOHNOT, S.M. 2004. Group size vs the activity budget of the hoolock gibbon. Folia Primatologica, 75, Supplement 1: 111-112 (Abstract only). ISSN: 0015-5713 E-ISSN: 1421-9980

CHETRY, D., CHETRY, R., BHATTACHARJEE, P.C. 2007. Hoolock: The Ape of India. Gibbon Conservation Centre, India, 1-133.

CHIARELLO A., DE MELO F. 2000. Primate population densities and Sizes in Atlantic Forest Remnants of Northern Espirito Santo, Brazil. International Journal of Primatology, N3, 379-396. http://dx.doi.org/10.1046/j.15231739.2000.99071.x

CHIVERS, D.J. 1984. Feeding and ranging in gibbons: a summary. In: The Lesser Apes. Evolutionary and Behavioural Biology, H. Preuschoft, D.J. Chivers, W.Y. Brockelman and N. Creel (eds.), pp.267-281. Edinburgh University Press, Edinburgh. http://dx.doi.org/10.2307/2408799

CHIVERS, D.J. 1984. Current issues and new approaches in primate ecology and conservation. In Primate Ecology and Conservation (Selected Proceedings of the Tenth Congress of the International Primatological Society; V. 2), Ed. J.G. Else and P.C. Lee, Cambridge University Press. http://dx.doi.org/10.2307/1939244

CHOUDHURY A. 2006. The distribution and status of hoolock gibbon, Hoolock hoolock, in Manipur, Meghalaya, Mizoram, and Nagaland in northeast India Primate Conservation, 20, 79-87. http://dx.doi.org/10.1896/0898-6207.20.1.79 COOP, R.L., KYRIAZAKIS, I. 2001. Influence of host nutrition on the development and consequences of nematode parasitism in ruminants. Trends in Parasitology, 17, 325-330. http://dx.doi.org/10.1016/s1471-4922(01)01900-6 COOP, R.L., HOLMES, P.H. 1996. Nutrition and parasite interaction. International Journal of Parasitology, 26, 951-962. http://dx.doi.org/10.1016/s0020-7519(96)80070-1

CRISTO'BAL-AZKARATE J.C., VEA J., ASENSIO N., RODRI'GUEZ-LUNA E. 2005. Biogeographical and floristic predictors of the presence and abundance of mantled howlers (Alouatta palliate mexicana) in rainforest fragments at Los Tuxtlas, Mexico. American Journal of Primatology, 67, 209 - 222. http://dx.doi.org/10.1002/ajp.20178

DAS, J., FEEROZ, M.M., ISLAM, M.A., BISWAS, J., BUJARBOURA, P., CHETRY, D., MEDHI. R., BOSE, J. 2003. Distribution of Hoolock Gibbon (Bunopithecus hoolock hoolock) in India and Bangladesh. Zoos' Print Journal, 18, 969-976. http://dx.doi.org/10.11609/jott.zpj.18.1.969-76

DASZAK, P., CUNNINGHAM, A.A., HYATT, A.D. 2000. Emerging infectious diseases of wildlife - threats to biodiversity and human health. Science, 287, 443449. http://dx.doi.org/10.1126/science.287.5452.443

ESTRADA A., COATES-ESTRADA R. 1996. Tropical rain forest fragmentation and wild populations of primates at Los Tuxtlas, Mexico. International Journal of Primatology, 17, 759-78. http://dx.doi.org/10.1007/bf02735263

GEISSMANN, T. 2007. Status reassessment of the gibbons: results of the Asian Primate Red List Workshop. Gibbon Journal, 3, 5-15.

GEISSMANN, T., GRINDLEY, M., MOMBERG, F., NGWE, L., MOSES, S 2008. Hoolock gibbon and biodiversity survey and training in southern RakhineYoma, Myanmar: Preliminary report. Myanmar Primate Conservation Program, BANCA, FFI, PRCF and Yangon University, Yangon. 31pp

GIBSON, T.E. 1963. The influence of nutrition on relationships between gastrointestinal parasites and their hosts. Proceedings of Nutrition Society, 22, 15-20. http://dx.doi.org/10.1079/pns19630006

GILBERT, K.A., SETZ, E.Z.F. 2001. Primates in a fragmented landscape: six species in central Amazonia. In: Bierregaard, R.O., Gascon, C., Lovejoy, T.E. \& Mesquita, R. (eds.) Lessons from Amazonia: ecology and conservation of a fragmented forest, Yale University Press, New Haven, CT. pp. 262-270.

GONZA'LEZ-ZAMORA, A., ARROYO-RODRI'GUEZ, V., CHAVES, O.M., SA'NCHEZ-LO, S., STONER, K.E., HERNA'NDEZ, R.P. 2008. Diet of Spider Monkeys (Atelesgeoffroyi) in Mesoamerica: Current Knowledge and Future Directions. American Journal of Primatology, 70, 1-13. http://dx.doi.org/10.1002/ajp.20625

GUPTA, A.K., SHARMA, N. 2005. Conservation of Hoolock Gibbon (Bunopithecus hoolock) in Meghalaya. In Conservation of Hoolock Gibbon (Bunopithecus hoolock) in Northeast India, Final Report of Wildlife Institute of India and United States Fish and Wildlife Services Collaborative Project (No. 98210-2- G153), A. K. Gupta (editor)

GUPTA, A.K. 2005. Conservation of Hoolock Gibbon (Bunopithecus hoolock) in Northeast India. A Final Report of Wildlife Institute of India and United States Fish and Wildlife Service's Collaborative Project (No. 98210-2-G153).

HARVELL, C.D., MITCHELL, C.E., WARD, J.R., ALTIZER, S., DOBSON, A.P., OSTFELD, R.S., SAMUEL, M.D 2002. Climate warming and disease risks for terrestrial and marine biota. Science 296, 2158-2162. http://dx.doi.org/10.1126/science.1063699

HOLMES, JC. 1995. Population regulation - a dynamic complex of interactions Wildlife Rescue, 22, 11-19. http://dx.doi.org/10.1071/wr9950011

HUDSON, P.J., RIZZOLI, A., GRENFELL, B.T., HEESTERBEEK, H., DOBSON, A. 2002. Ecology of wildlife diseases. Oxford University Press, Oxford. ISBN-10: 0198506198

JOHNS, A.D., SKORUPA, J.P. 1987. Responses of rainforest primates to habitat disturbance. International Journal of Primatology, 8, 157-191 http://dx.doi.org/10.1007/bf02735162
KAKATI, K. 1997. Food Selection and Ranging in the Hoolock Gibbon (Hylobates hoolock) in Borajan Reserve Forest, Assam. M.Sc dissertation, Wildlife Institute of India, Dehradun, Uttarakhand, India

KAKATI, K. 2006. Fragment-living - a study of hoolock gibbons in Assam, India. The Gibbon's Voice, 8(1), 1-4.

KAKATI, K., RAGHAVAN, R., CHELLAM, R., QURESHI, Q., CHIVERS, D.J. 2009. Status of western hoolock gibbon (Hoolock hoolock) populations in fragmented forests of eastern Assam. Primate Conservation, 24, 127-137. http://dx.doi.org/10.1896/052.024.0111

KOSKI, K.G., SCOTT, M.E. 2001. Gastrointestinal nematodes, nutrition and immunity: breaking the negative spiral. Annual Reiew of Nutrition, 21, 297-321. http://dx.doi.org/10.1146/annurev.nutr.21.1.297

LAMBERT, F. 1989. Fig-eating by birds in Malaysian lowland rainforest $\begin{array}{lllll}\text { Journal of } & \text { Tropical } & \text { Ecology, }\end{array}$ http://dx.doi.org/10.1017/s0266467400003850

MITTERMEIER R.A. 1986. A global overview of primate conservation. In Primate Ecology And Conservation (Selected Proceedings of the Tenth Congress of the International Primatological Society; V. 2), Ed. J.G. Else and P.C. Lee, Cambridge University Press. http://dx.doi.org/10.1017/s0030605300026740

MOIR, R.J. 1994. The carnivorous herbivores. In: The Digestive System in Mammals: Food, Form and Function, D. J. Chivers and P. Langer (eds.), 87-102. Cambridge University of Press, Cambridge, UK. http://dx.doi.org/10.1017/cbo9780511661716.008

MOLUR, S., JONES, D.B., DITTUS, W., EUDEY, A., KUMAR, A., SINGH M., FEROZ, M.M., CHALISE, M., ORIYA, P., WALKER, S. (eds.) (2003). Status of South Asian Primates. 2003: Conservation Assessment and Management Plan (C.A.M.P.) Workshop Report 432pp.

MOLUR, S., WALKER, S., ISLAM, A., MILLER, P., SRINIVASULU, C., NAMEER, P.O., DANIEL, B.A., RAVIKUMAR, L. (eds.). 2005. Conservation of Western Hoolock Gibbon (Hoolock hoolock hoolock) in India and Bangladesh. Population and Habitat Viability Assessment (P.H.V.A.) Workshop Report, Coimbatore, India.

MOOTNICK, A.R., GROVES, C.P. 2005. A new generic name for the hoolock gibbon (Hylobatidae). International Journal of Primatology, 26, 971-976. http://dx.doi.org/10.1007/s10764-005-5332-4

MUANGKRAM, Y., TAWEETHAVONSAWAT, P., PATTANARANGSAN, R. 2006. A survey of intestinal parasites in gibbons at Krabokkoo Breeding CenterChachoengsao Province, Thailand. In Proceedings of AZWMP, Chulalongkorn University Faculty of Veterinary Science, Bangkok, Thailand. PDF Version downloaded from http://www.vet.chula.ac.th/vet2014/Ebook/ebook/azwmp2006/_P2_\%20RE\%201 2.pdf. on March, 2014

MUZAFFAR S.B., ISLAM M.A., FEEROZ M.M., KABIR M., BEGUM S., MAHMUD M.S., CHAKMA S., HASAN M.K. 2007. Habitat Characteristics of the Endangered Hoolock Gibbons of Bangladesh: The Role of Plant Species Richness. Biotropica, 39(4), 539-545. http://dx.doi.org/10.1111/j.17447429.2007.00298.x

NATH, B.G., ISLAM, S., CHAKRABORTY, A. 2012. Prevalence of parasitic infection in captive non-human primates of Assam State Zoo, Indian Veterinary World, 5 (10), 614-616. http://dx.doi.org/10.5455/vetworld.2012.614-616

NELSON, R.J., DEMAS, G.E. 2004. Seasonal patterns of stress, disease, and sickness responses. Current Directions in Psychological Science, 13, 198-201. http://dx.doi.org/10.1111/j.0963-7214.2004.00307.x

OFTEDAL, O.T. 1991. The nutritional consequences of foraging in primates: the relationship of nutrient intakes to nutrient requirements. Philosophical Transactions of the Royal Society London. 334, 161-170 http://dx.doi.org/10.1098/rstb.1991.0105

PERES, C.A. 1994. Primate responses to phonological changes in an Amazonian Terra Firme Forest. Biotropica, 26(1), 98-112. http://dx.doi.org/10.2307/2389114 RAJA, M.M. 2012. Coprologic Study of Gastrointestinal Parasites of Carnivores and Small Mammals at Dhaka Zoo, Dhaka. Thesis. Bangladesh Agricultural University, Mymensingh.

ROVERO F., STRUHSAKER T.T. 2007. Vegetative predictors of primate abundance: utility and limitations of a fine-scale analysis. American Journal of Primatology, 69, 1242-1256. http://dx.doi.org/10.1002/ajp.20431

SATI, J.P. 2011. Current status of Western Hoolock Gibbon Hoolock hoolock Harlan in West Garo Hills, Meghalaya, India. Journal of Threatened Taxa, 3(2), 1520-1526. http://dx.doi.org/10.11609/jott.o2292.1520-6

SCOTT, M.E., DOBSON, A.P. 1989. The role of parasites in regulating host abundance. Parasitology Today, 5, 176-183. http://dx.doi.org/10.1016/01694758(89)90140-3

SRIVASTAVA, A. 2006. Conservation of threatened primates of Northeast India. Primate Conservation, 20. http://dx.doi.org/10.1896/0898-6207.20.1.107

STEVENSON, P.R. 2001. The relationship between fruit production and primate abundance in neotropical communities. Biological Journal of the Linnean Society, 72, 161-178. http://dx.doi.org/10.1111/j.1095-8312.2001.tb01307.x TABARELLI, M., MANTOVANI, W., PERES, C.A. 1999. Effects of habitat fragmentation on plant guild structure in the montane Atlantic forest of southeastern Brazil. Biological Conservation, 91, 119-127. http://dx.doi.org/10.1016/s0006-3207(99)00085-3 
TERBORGH, J. 1983. Five New World Primates: A Study in Comparative Ecology. Princeton University Press, Princeton, NJ. ISBN 069108338X 0691083371

TILSON, R.L. 1979. On the Behaviour of Hoolock gibbons during different seasons in Assam, India. Journal of the Bombay Natural History Society, 76, 116.

VELLAYAN, S. 1981. Chemical composition and digestibility of natural and domestic food of the Lar gibbon (Hylobates lar) in Malaysia. MSc Thesis, Universiti Pertanian Malaysia.

WALKER, S., MOLUR, S., BROCKELMAN, W.Y. 2007. Western hoolock gibbon, Hoolock hoolock (Harlan, 1831). In: Primates in peril: The World's 25 most endangered primates, 2006-2008, R. A. Mittermeier et al. (eds.), pp.18, 30 Primate Conservation, 22, 1-40. http://dx.doi.org/10.1896/052.022.0101

WOLFHEIM, J.H. 1983. Primates of the World: Distribution Abundance and Conservation. Seattle: University of Washington Press. ISBN 10: 0295958995 ISBN 13: 9780295958996 